\title{
SOCIAL THEORY AND ARCHITECTURE
}

\author{
A B S S T R A C T
}

The role of architecture through history has always been important because it is a physical frame of social life and also a symbol of social values and aspirations. Architectural creations are influenced by social thought. Modernism is an outstanding example of how social goals have directed planing of the cities. After having analyzed the conditions of its emergence and its characteristics this paper points out the changes brought about by postmodernism. In the end, the attention has been drawn to the place architecture holds in the city of consumption. 


\section{INTRODUCTION}

This paper analyzes complex relationship between social theory and architecture. Architecture could be perceived as means for intervention in social reality and is significantly influenced by social theory. The relationship between architecture, society and theory is multilayered. Firstly, architecture is visible and palpable physical structure that has strong and everyday impact on people. Architecture is a permanent stage of men's events (Rossi, 2008:22). Secondly, given that construction investments are rather high, before the building process starts a debate goes on among the experts about the style of the object, the material to be used, etc. Consequently, in the realm of architecture, there have been many arguments in favor or against modern and post-modern. The third, architecture has special role in creating the image of the city, making it distinguishable and memorable. At the end of the $20^{\text {th }}$ century the processes of commercialization and commoditization of architecture were intensified. The fourth, from the very beginnings of cities, the power of ruling groups was materialized in the built environment. During the $20^{\text {th }}$ century besides the state and the church, transnational corporations appeared as concurrent stakeholder, which expressed their power by monumental headquarter buildings. Nowadays, each built structure, regardless of its use, must be architecturally attractive in order to be noticed.

\section{MODERNISM}

At the outset of the $20^{\text {th }}$ century different architectural movements emerged which were influenced by the social utopists. The tradition of idealism included De Stijl, Purism, Constructivism, Expressionism, Dadaism and Super realism. Perceived on a broader scale, Modernism in architecture is linked to the conditions of the industrial development and demand for radically new spatial planning and building. The significance that industry had in the society was in accordance with the notion that flat was a "machine for living". Modernism is characterized by excessive use of materials such as concrete, glass and steel, whereas the very designing and building are based on the principles of rationality and functionality.

Modernism has gradually been developing during the first half of the $20^{\text {th }}$ century. After the World War Two, the International style, deprived of social idealism, became a dominant architectural concept, which overwhelmed other styles of architectural modernism, such as constructivism and expressionism. However, it has also been criticized since the sixties in the USA and Europe, primarily in France. 
The idea of its leading architects Ludwig Mis van der Roe, Walter Gropius and Le Corbusier was to invent universally applicable style that would go beyond the cultural frontiers of the countries. The building techniques would follow the same rules in Japan, China, European countries or the USA. The theoretical base of spatial urban planning was the Athens Charter (1933) which incorporated the principles of modern urbanism. It is based upon Le Corbusier's concept of cities, in which urban functions are separated into special zones to satisfy basic human needs - residence, work, transportation, exchange, leisure.

The city built on these principles is antitraditional, antihistorical, named the radiant city, the city of sun, space and greenery. The aim of such planning was to overcome the negative consequences of capitalist urban development - transport disconnection of its parts, impassable streets, zone malfunctioning, hygiene problems and accessibility to nature. The foundation of modern architecture is functional rationality, rationalism of spatial structure and its organizing in accordance with human needs (Bogunović, 2005: 1328).

In aesthetic sense the category of "beauty" means suitable to its purpose. Thus, functional and useful objects became the main goal architects are striving for, not the pure beauty of form. The abstract geometry, collectivism, universality and impersonalism are the aesthetic criteria. Straight line, clear facade, continued surfaces, open forms, are the proclaimed ideals of architects. Thus, the detail, as an element of creativity of the architect, is rejected. In order that houses are built in accordance with the postulate of "beauty of suitability" or "machine aesthetics" they ought to be efficient, so they often have the form of a machine, a plane, a car or a ship (Bogunović, 2005).

Unnational and unhistorical elements predominate in space, whereas historical styles and ornaments are denied. Thus, the rejection of ornaments helped the disconnection with the past and creation of architecture with universal face. New industrial cities needed new residential forms and new spatial organization, so the International style had to fulfill that task. Le Corbusier planned his machines for living, and Mis van der Roe thought of an architecture that responded to technological society (Malpas, 2005). Universal principles of architectural modernism, ideologically neutral, were implemented both in capitalist and socialist urban planning. After the World War Two the capitalist cities underwent an intensive construction of social residential flats, constructed by prefabrication process that significantly reduced the construction costs. The social flats were intended for those 
who were not able to buy one, primarily members of the working class. Although in capitalist cities modernism is noticed in some public buildings too, it is predominantly applied in those social residences.

As many critics of modernism have noticed, emancipation claims turned into dictate. In fact, the aim of modernism was a human one - new man in new residential conditions. But, the role of architecture in creating a new society was overestimated. The aim was to construct as many flats as to satisfy greater number of residents; to overcome problems of neglected industrial slums of the $19^{\text {th }}$ century, poor sanitary and infrastructural conditions of living. In practice, residence was based on the principles of functionality and necessity. Privacy was ignored. There have emerged many ideas on collectivization of residence, whereas some extreme examples were realized in the USSR. The city, a "social condenser", was to create a new individual - a socialist man. The most important constructions were workers' clubs and residential buildings. Special attention was paid to minimalization and standardization of living space - 9 sq.m per person - beside the use of common premises and services. A unit of $\mathrm{F}$ type would be a part of a communal residential building, a homecommune. Extreme examples of taylorization of everyday activities have been noticed, with prescribed time required for each activity.

One of the consequences of modernism is the purist style, so that built objects look like hospitals, whether it concerned the residential, governmental, scientific or cultural building. The practice of reproducing identical objects (schools, hospitals, health and cultural centers, municipal and government buildings) produced a labyrinth of undistinguishable objects. Lack of clear landmarks makes it impossible for people to feel more intimate ties with their neighborhood, and intensifies the feeling of impersonality and mediocrity. Moving people from their traditional environments to uniformed settlements caused unpredictable consequences. Social planers determined the living conditions asking people to conform to functional and rational scheme of their new residential forms. Completely same residential buildings, with identical streets and spatial geometry, led to the alienation of substantial number of citizens. It happened that whole quarters in different cities were designed by the same architect, so that cities lost their authenticity and looked alike. The incapability of adjusting oneself to a new situation caused social isolation, vandalism and crime. People were longing for an authentic personal existence which could not be realized in impersonal, uniformed cities, the products of international style. 
The concept of urbanism of Le Corbusier, which included separation of functions, zoning of the city and its typifying, was often criticized because it created a "repressive space" which does not respect the autonomy of its residents, their particularities and reactions to the built space. In the very school there was a disagreement and critique of the mechanicistic application of the Athens Charter, which ignored the significance of city "core", the centre, and also the importance of feeling a sense of belonging and identification with the city, home, neighborhood and street. The "zoning principle" caused urban segregation and left the city without a centre, which was a place of encounter.

\section{POSTMODERNISM}

The critiques of the theory of modernism led to the emergence of a new movement - postmodernism - the theories of which rejected unquestioned progressive development of humanity and the belief that science could be a means for successful organization of social life. Urbanism and architectural practice were influenced by changes in social theory, which reflected the changes in social reality. Thus, architects rejected meta-narratives and, above all, rationalism of modern architecture.

Given that there is an acceptable definition of modern architecture as an universal international style, based on the facts of new construction means, suitable to the new industrial society, with the aim to influence social changes in its taste and perception as well as in its social organization (Jencks, 2003: 449), therefore it is less complicated to define characteristics of postmodernism.

The beginning of postmodernism in architecture could be more precisely fixed than in other spheres. Charles Jencks determined the exact date and time of the end of modernism being on 15 July 1972 at 3:32 p.m. which many authors in the field of modern architecture have accepted and used (Jencks, 1985 and Apinjanezi, Garet, 2002). Although this date is used symbolically, the event that took place then was an obvious proof of inhumanity and uniformity of one style, whereas the very act meant confession of its total defeat. On that day the housing project Pruitt-Igoe (Minoru Yamasaki) in Saint-Luis, built for people with low incomes, was knocked down, because of its unsuitability for living. The irony was greater for the fact that the project's architect was awarded by the American Institute of Architecture. It was proved that that kind of projects designed by international style failed to make city a human space for living, capable to meet people's needs. 
As a reaction to modern architecture, in the sixties there appeared a hybrid, eclectic style, which mixed architectural principles in order to communicate with broader public. There started the development of contextualism of Aldo Rossi, who emphasized urban contrasts, places of encounters and historical collages. The roles of street, square and crossing were reaffirmed. Contact and cooperation with future users is necessary before the building process begins.

Robert Venturi, Charles Moore, Robert Stern and Michael Graves formulated the principles of postmodernism. The Venice Biennale of architecture in 1980, with the theme on The presence of the past, meant the acceptance of historicism. However, the movement is not monolithic; it includes metaphorical buildings from the Sydney Opera House (Jørn Utzon, 1973) and Guggenheim Museum in Bilbao (Frank Gehry, 1997), to Georges Pompidou Centre in Paris (Renzo Piano \& Richard Rogers, 1977), with emphasized characteristics of modernism.

Venturi thinks that the world of Disneyland and Las Vegas are closer to people than everything architecture had offered to them up to date. We should learn from Las Vegas, the city which developed spontaneously and in unplanned manner. Learning from already existing urban surroundings is the way to become revolutionary. "For an artist, the creation of a new may mean the choice of the old and already existing. Pop artists learnt that again" (Venturi in Sim, 2002:200). Rejecting the architectural universalism Venturi pleads for local style, pointing to historical past, which means the return of ornament, symbol, parody and quotation. By this recycling of styles the past is present again, out of the frame of linear explanation of history. Postmodern age represents a different way towards history. Theoretically speaking, the period of postmodernism through fragmentation of everyday experience makes the idea of history particularized. Although one may think that postmodernism is a new way to overcome the tradition, one is dealing, in fact, with radically different view that rejects all ideas of progress through history. The new method of modernism is particularization of history, whereas joining its parts into a single big story is impossible task. The impossibility to define history by a single notion that includes the diversity of all its manifestations clearly separates postmodernism from modernism (Vattimo, 1988). In his opinion the way out from the modern age is not in criticizing it, which shows that our mind still is not free from modernistic view, and is still using the linear model when explaining the changes of historical epochs. "We may define postmodernism as something that is [...] in relationship with modernism: it accepts it and takes it over, carrying it inside itself as the trace of some illness that it is still recovering from, thus continuing it but also distorting it" (Vattimo, 1988: 77). 
The characteristics of new architecture emphasize the pluralism and heterogeneity of cities and global culture and acceptance of diversity of different cultural models and visual codes of the users. From participative architecture to close consultations with clients, the new architecture insists on broader ecological and urban frames in which the built forms are placed. Post-modern architecture uses non-Euclid geometry - curved line, bubbles, folds, furrows, twisted and scattered patterns - structural networks and forms (Jencks, 2007: 2). One example of post modernistic architecture is revitalization of abandoned industrial city districts, factories and warehouses. The importance of medieval square tradition, denied by modernism, has been especially emphasized.

In contrast to modernism, postmodernism respects already existing styles, regional identities and local traditions. Through process that Charles Jencks calls double coding, the contemporary postmodern architecture is eclectic, because it borrows styles from different periods, and draws on already existing building solutions. Double coding means that a single architectural product is multilingual, which enables different perceptions of the building. On one side, the redundant level of an achievement would address an average man who perceives and consumes architecture in his everyday life. On the other side, there is an ironic level which is perceived by those interested in stylistic and architectural features of the object (Jencks, 1985). Here, one deals with recycling, what Jencks calls radical eclecticism, which, in fact, means return to the past things through quotations which are not transferred directly, but are recontextualized and transferred in such a way that they make impression of surroundings which refers to wide spectrum of styles and epochs, thus creating residential space with multiple layers. On the contrary, "radical eclecticism" starts projecting in accordance with taste and language that prevail in certain place, and architecture is extremely coded (by many redundant signs), so that people of different tastes - both mass and elite - can understand it and use it" (Jencks, 1985: 196). Naturally, the models need not be too obvious. The best architects cannot be classified in any movement because the architecture they create has many various meanings.

The key point for post-modern architecture is its relationship towards history. The interest in history of postmodern architects is not shown in bare citation. The crucial idea is to create such architectural objects based on knowledge of historical facts that are specific for every region and country. Architects consider that skyscrapers of the international style, ignoring historical structure of the city and being inadequate to meet the human needs, „destroy” the city. Maybe, the best formulation of demands for respecting history 
was provided by Kenneth Frampton. He fought for the idea of critical regionalism, which, in his opinion, was a much better solution than postmodernism. He rejected postmodernism thinking that it had no intellectual capabilities, but was bare recycling and populism (Malpas, 2005).

Modern architecture was considered a means to reach the goal - to create a citizen of correct/healthy behavior. Contrary to Corbusier's universal, functional skyscraper, which could be built anywhere without respecting the uniqueness of the place, the architecture of postmodernism promoted the house that would suit its future users.

This ideal type concept of architecture of postmodernism, that built objects are to meet human needs, does not take into consideration building objects for a consumers/tourists, which is a very intensive practice all over the world. The symbol of industrial society was the city of production, characterized by modernistic economy and functionality, while the city of post-industrial society was a city of consumption. The latter is to enable the service/ creative class to lead certain style of life. The shopping mall, as an inevitable object of post-modern city, stands out, which also has the characteristics of universal skyscraper - it can be located anywhere without paying attention to local features - with important difference that it does not aspire to sun and greenery, but includes artificial streets, light, fragrance and greenery. Thus, so-called non-places are integral part of contemporary city for its function is only to transport people, so they are places for consumption. Non-places are built objects and roads important for rapid circulation of people and goods (high-ways, loops, bridges, airports) and also transportation means; non-places are also shopping centers and camps for refugees (Oze, 2005:36). Non-place is defined as a negation of place, space that cannot be defined as space that one could identify, a place where people have relations with each other, or place where one meets history (Oze, 2005:75). Non-place is the expression of globalization of space which means implementation of the same concepts for various locations with the respect for local specialties.

Most often analyzed post-modern construction is Westin Bonaventure Hotel in Los Angeles, designed by John Portman. Frederic Jameson and Jean Baudrillard, the most prominent authors of postmodernism, also wrote about it. Jameson writes that this building is a total space, with its inside world, isolated from the outside one, existing in its own, specific way. The 'glass skin', as Jameson calls the exterior side of the Hotel, hiding the interior, reflects only a distorted picture of its surroundings. Escalators and lifts replace human movement, being symbols of 
its own movement. Thus, the walk inside the Hotel is, according to Jameson, emphasized, symbolized and replaced by transport machines. The Hotel is built in a way that its internal arrangement distracts the attention of the spectator from the form, so one cannot have the sense of perspective and volume. Thus we have got a hyperspace which completely comes over one's eyes and body. At the end of his analysis of Hotel Bonaventure Jameson writes:

„So I come finally to my principal point here, that this latest mutation in space - postmodern hyperspace - has finally succeeded in transcending the capacities of the individual human body to locate itself, to organize its immediate surroundings perceptually, and cognitively to map its position in a mappable external world. And I have already suggested that this alarming disjunction point between the body and its built environment - which is to the initial bewilderment of the older modernism as the velocities of space craft are to those of the automobile - can itself stand as the symbol and analogue of that even sharper dilemma which is the incapacity of our minds, at least at present, to map the great global multinational and decentred communicational network in which we find ourselves caught as individual subject" (Jameson, 1995 :66).

Baudrillard sees Los Angeles as a city of simulation and simulacrum par excellence. He analyzes its transport, roads, banks and its general look. He also writes about Hotel Bonaventure in his book America. He agrees with Jameson that the Hotel's glass windows reflect the outside world returning its own picture to it. The Hotel is a micro world, and thus is apart from the city, instead of being a part of it. He writes about his confusion and dizziness while staying in the Hotel, and concludes:'It is clear illusionistic architecture, clear spatial-temporal trick, is it still an architecture? Ludic and hallucinatory, is this post-modern architecture?" (Baudrillard, 1993: 50).

Postmodernism in architecture is perceived as radicalization of modernism, which continues to use latest building materials and rejects uniformity and social engineering. This new movement in architecture offered ironical quotations, parodies and pastiche of premodern building, recontextualizing and reincorporating it into futuristically designed new construction. One may say that the goal of postmodern architecture is humanization of man's environment and not its transformation with an aim to reduce a man to several functions and to adapt their lives to predetermined rational scheme. Hence, one can conclude that postmodernism is not opposed to modernism, rather they are two aspects of the same movement, and postmodernism could be understood as modernism which admitted its errors and abandoned functionalistic limits. 
"Architecture of postmodernism breaks the boundaries of monopoles and thus becomes free to involve traditional potentials and reaccept covered roads of modernism. It turns against self-annulment of failed modernism, relativises its broader intentions and principally goes beyond traditional boundaries of modernity. Contemporary times are for postmodernism important as it were for modernism. But, incorporating traditional potentials, it is basically more open for larger number of models that was never the case with modernism" (Welsh, 2000:118).

Postmodern architects were developed from modernism but they tend to surpass the unsuitability of its ideology and language. They accept new technology and materials, but they reject the paternalism and utopism and their aim is communication with the users. In the table below the characteristics of modern and postmodern architecture have been provided. (Table 1)

\section{POSTMODERN CITY}

This part of the paper points out the changes of the contemporary city and the significant role of architecture. Postmodern city is oriented towards consumption, in the economy in which tertian ad quartile sectors dominate. Traditional industrial production is decreasing, while service economy is vigorously developing. Also, industry of culture and economy of symbols are becoming more important. There are big investments in creating and spreading the images of contemporary city, in which its architecture plays the main role. Built objects are the symbols of cities which help to identify them.

\begin{tabular}{|l|l|}
\hline \hline Modernist & Postmodernist \\
\hline \hline $\begin{array}{l}\text { space shaped according to an overarching social } \\
\text { objective }\end{array}$ & space is independent and autonomous \\
\hline $\begin{array}{l}\text { architecture and planning aim to integrate the } \\
\text { metropolis }\end{array}$ & $\begin{array}{l}\text { architecture and urban design reflect the basic } \\
\text { fragmentation of the metropolis }\end{array}$ \\
\hline imposes an external, utopian vision & celebrates localized vernacular traditions \\
\hline commerce-oriented & market-oriented \\
\hline geographically centralized & geographically decentralized \\
\hline austere, inflexible & playful, eclectic \\
\hline authoritarian & consultative \\
\hline rectangular, unadorned & irregular, decorative \\
\hline
\end{tabular}


The brand of the city is very important because it provides success in the market of capital investment, business, retail and residential space, entertainment, tourist destinations, cultural and sport activities (Petrović, 2009). For instance, the organization of spectacles (the Olympic games are an outstanding example) with unprecedented architectural design, gentrification projects in cities all over the world, all these manifest the financial power of the private sector, but also successful management of local and federal administration.

Abandoned and deteriorated residential city districts and industrial objects called for new strategic tactics. Thus authorities and planners undertook a wide-scale action in order to revitalize those structures and make them suitable for up-to-date uses and needs. Gentrification is primarily caused by deindustrialization, i.e. relocation of industrial objects, but also by changes of life style of the new, service class members. Revitalized objects - business and shopping centers, residential buildings, galleries and museums, concert halls, restaurants - attract tourists, but are primarily oriented towards the members of creative class.

Apinjanezi, R. i Garet, K. (2002), Postmoderna za početnike, Hinaki, Beograd

Bodrijar, Ž. (1993), Amerika, Buddy Books, Beograd

Bogunović, S. G. (2005), Arhitektonska enciklopedija Beograda XIX i XX veka (I-III), Beogradska knjiga, Beograd

Dženks, Č. (1985), Jezik postmoderne arhitekture, Vuk Karadžić, Beograd

Dženks, Č. (2003), Moderni pokreti u arhitekturi, Građevinska knjiga, Beograd

Dženks, Č. (2007), Nova paradigma u arhitekturi, Orion Art, Beograd

Hannigan, J. (1995), The postmodern City: A New Urbanization, Current Sociology, Vol. 43, No. 1, pp. 152-215

Jameson, F. (1995), Postmodernizam u kasnom kapitalizmu, Art press, Beograd

Malpas, S. (2005), The Postmodern, Routledge, London - New York

Ože, M. (2005), Nemesta, Biblioteka XX vek, Beograd

Petrović, M. (2009), Transformacija gradova: ka depolitizaciji urbanog pitanja, ISI FF, Beograd 
Rosi, A. (2008), Arhitektura grada, Građevinska knjiga, Beograd

Sim, S. (2002), Irony and Crisis: A Critical History of Postmodern Culture, Cambridge, Icon Books

Vattimo, G. (1988), Postmoderno i kraj povjesti, u: Flego, G. Postmoderna nova epoha ili zabluda, Naprijed, Zagreb

Vatimo, Đ. (1991), Kraj moderne, Bratstvo-Jedinstvo, Novi Sad

Velmer, A. (1987), Prilog dijalektici moderne i postmoderne, Svetovi, Novi Sad

Velš, V. (2000), Naša postmoderna moderna, Izdavačka knjižarnica Zorana Stojanovića, Sremski Karlovci 